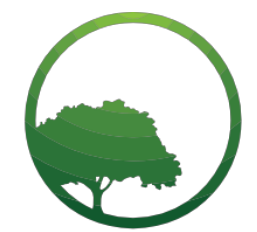

Business \& Social Science IJRBS

\section{Research in Business and Social Science}

IJRBS Vol 7 No 2, ISSN: 2147-4478

Contents available at www.ssbfnet.com/ojs

\title{
Prospects and Competitiveness in Creative Economy: Evidence from Indonesia
}

\section{Sigit Setiawan}

Senior Researcher at Fiscal Policy Agency, Ministry of Finance Indonesia

\begin{abstract}
A growing number of unimaginable cross-border start-up businesses have emerged in the ASEAN and global trade map, along with the development of communication and information technology that negates national borders. The new sector-referred to as creative economy - requires and utilizes high specific knowledge, skills and creativity. With literature review and descriptive analysis method, this study aims to: firstly, analyze the prospects for Indonesian creative economic sector in the ASEAN market; secondly, analyze the competitiveness of Indonesia's creative economic sector in ASEAN and the world levels. By making comparison of the data in two periods (2002-2006 and 2014-2015 periods), it can be concluded that the average contribution of creative economy to Indonesian economy continues to increase. The increase goes to the added value, the sectoral contribution to GDP, the provision of employment, and the sectoral absorption of national labor. The prospect of Indonesian creative economy in the ASEAN market lies in the growth of potential customers from the middle class. The number of Indonesian middle class will continue to increase. By adopting and analyzing the output of the Global Creativity Index model, it can be concluded that the competitiveness of Indonesian creative economy in ASEAN and the world is still weak. The weak competitiveness is due to low technology index and talent index. However, based on the findings from previous studies in several regions in Indonesia, it appears that Indonesian people have great potential creativity to develop.
\end{abstract}

Key words: Creative Economy, Competitiveness, Creativity, ASEAN

JEL classification: $023, M 21,035$

Submitted: 14.08.2018 - Accepted: 15.10.2018

\section{Introduction}

Prospects and challenges always emerge and exist in the today's international business context. A growing number of unimaginable cross-border start-up businesses have emerged in the ASEAN and global trade map, along with the development of communication and information technology that negates national borders. The existence of Facebook, Google, WhatsApp, Instagram, Amazon.com, JD.com, AliBaba, E-Bay, Gojek, Uber, and Grab are some illustrations of an originally start-up business which is subsequently growing to be a big rival for conventional business.

Other fast growing business is entertainment related businesses. This kind of business is also growing in more various ways, which is combined with the latest technology, has created much contribution to entrepreneurship and employment. Even now, the existence of a variety of expert consulting services in 
various fields is no longer limited by the necessity of physical contacts between the service providers and their clients.

There is a similarity appears in the new bussinesess economic sectors: all of them need and utilize high specific knowledge, skills and creativity. These various bussinesses are inadequate if they are classified into the existing economic sector, thus a new economic sector the so-called creative economy is born (Howkins, 2013). As an emerging and growing economy, Indonesia is required to be able to take advantage of the opportunities from the existence of the new, so-called creative economy to reach the dream of Indonesian prosperous society.

This paper has two objectives. The first is to analyze the prospect of Indonesian creative economy sector in the ASEAN and ASEAN partners market. The second is to analyze the competitiveness of Indonesian creative economic sector at the ASEAN and world levels.

\section{Literature Review}

\section{The Definition and Scope of Creative Economy}

The term of creative economy was first introduced by John Howkins (2013) - a British writer and media manager in his book entitled "The Creative Economy: How People Make Money from Ideas". The existence of a wave of creative economy that occurred in the United States was pictured by Howkins in his book. In his book, Howkins (2013) defines creative economy as "the value creation, as a result of ideas". He further explained that creative economy is "an economic activity of society that uses most of the time to create ideas, not just does routine and repetitive things. In the view of society, creating ideas is a must to advance further to achieve a better world." Howkins adopts the terminology of creative economy for 15 types of industries that vary from art to science and technology. According to Howkins estimates, this creative economy was worth US $\$ 2.2$ trillion in 2000 and grew in the range of $5 \%$ per year. Howkins' coverage is very broad because it covers not only cultural goods and services, but also children toys, games, and the entire domain of research and development.

United Nations, UNDP, and UNESCO (2013) include two types of industries: cultural industries and creative industries as industries involved in the creative economy. Another version by UNCTAD (United Nations Conference on Trade and Development) defines creative economics as "a developing concept based on creative assets that have the potential to create economic growth and development." Furthermore, the UK Department of Culture, Media and Sport (DCMS) defines the creative economy as industries that are initiated from individual creativity, skills and talents, and have the potential to create wealth and employment through the creation and the use of intellectual property and content. Indonesian government defines creative economy as creative economy as "a new economic era after agricultural economy, industrial economy, and information economy, which intensifies information and creativity by relying on ideas and knowledge from human resources as the main production factor in its economic activities." Such a definition can be found in the 2009-2015 Indonesian Creative Economy Development Blueprint. Meanwhile, BEKRAF- a new institution established by President Jokowi to handle creative industries has included 16 sectors (see Table 1) in the creative industry category.

Table 1: Creative Industry Subsectors According to BEKRAF

\begin{tabular}{|l|l|l|l|}
\hline No. & Sectors & No. & Sectors \\
\hline 1. & Games Application and Development & 9. & Crafts \\
\hline 2. & Architecture & 10. & Culinary \\
\hline 3. & Interior design & 11. & Music \\
\hline 4. & Visual communication design & 12. & Publishing \\
\hline 5. & Product Design & 13. & Advertising \\
\hline 6. & Fashion & 14. & Performing Arts \\
\hline 7. & Film- Animation -Video & 15. & Art \\
\hline 8. & Photography & 16. & Television and Radio Content \\
\hline
\end{tabular}

Source : BEKRAF (2016) 


\section{Creativity Requirements}

To be able to develop creativity, an individual or a group of individuals requires creative capital and creative space. In Matthews (2008), some experts mention various definitions of creative capital. The summary derived from the opinions of Kao, Nystrom, Ames, and Runco, states creative capital as the ability and the potential of individuals or groups of individuals to produce innovation, creativity, design, or entrepreneurship. Those output can be in the form of new ideas, or the results of application and incorporation of old ideas into new ideas. In the context of a company, a creative process occurs - with the entrepreneurial spirit - to produce new business ideas and business models.

Still in Matthews (2008), other experts McWilliam \& Dawson argue that creative capital is one of the valuable resources in various creative workplaces today, which can be found in a variety of industries such as computing, engineering, architecture, science, education, arts and multimedia. The government and nonprofit institutions are included by Rittel \& Webber into sectors that need creative ideas to solve problems and provide solutions to the problems in the community as well as internal government institutions. Furthermore, Florida \& Goodnight (2005) share similar argument: creative capital is the capacity possessed by creative thinkers to produce ideas, which can be realized into valued goods and services.

The existence of a company - as a group of individuals - can be part of creative capital and can play a major role as a locomotive for technological innovation. Joseph A. Schumpeter (1942) in his book entitled "Capitalism, Socialism, and Democracy" wrote that large companies have the market power needed to accelerate the level of innovation (Nicholas, 2013). The Schumpeter statement is true from the innovations created in big companies such as Microsoft, Apple, Toyota, Mercedes, and Samsung. Meanwhile Nicholas (2013) further states other literatures entitled "Market Share" (written by Blundel and van Reenen), "Competition" (written by Nickell), and "Competitive Advantage" (written by Porter) argue that the companies with proportionally smaller size will tend to innovate more than large ones. The author also finds the truth in this opinion seeing the mushrooming start-up companies today that are very innovative and then grow big like Facebook, Google, WhatsApp, Gojek, and Uber.

The emergence of newly remarkable technology created by those companies can cause eroding profit margins and bankruptcy in existing companies in the market (creative destruction) (Nicholas, 2013). The appearance of new Google Android application technology made some famous mobile phone manufacturers such as Motorola, Nokia, and Blackberry fall into a bankruptcy. Meanwhile, some niche market not captured by large companies due to its lower value can be taken by other smaller companies which can create innovation for the market (disruptive innovation) (Christensen, et al., 2015). For an illustration, the emergence of Canon and Minolta, manufacturers of photocopy personal machines which is able to fill the market niche of small corporate offices of relatively small value that Xerox has ignored in the period before 1980.

With reference to Martin, Morris, Rogers, and Kilgallon (2010), creative space can be explained as an environment for human activities that supports the ability of individuals or groups of individuals to carry out creative activities. Creative space is not merely a physical environment, but also covers psychological space, virtual space, personal psychological space and biological space.

Psychological space for learning and creativity is shaped by many individual characteristics and the context of places: residence, workplaces, community places and places of learning. Virtual space includes not only the connection between individuals and local groups but also in larger community through cyberspace networks. Biological space can be characterized by the physical and mental abilities of individuals involved in learning. Various individual physical disabilities (eg. autism and dyslexia) can potentially cause learning problems.

The economy will grow over time if supported by the appearance of various new goods and services; and it is impossible without creativity. There is certainly market selection process in there and not all creative ideas will successfully gain acceptance from the consumers and markets. Since creativity emerges from a combination of creative capital and creative space, government support in facilitating the existence of those two things becomes important (Department of Trade and Industry, 2005). 


\section{Research Methodology}

The method adopted to analyze the first issue is literature review and descriptive analysis using World Bank data. To analyze the second issue, the author will adopt and analyze the output of the Global Creativity Index model to conduct a benchmarking analysis between Indonesia and ASEAN countries and also the world. This study assumes that a nation's level of creativity is in line with the level of competitiveness that a nation's creative economy acquires.

\section{Model Global Creativity Index}

The Global Creativity Index which is adopted by the World Economic Forum is a new model of economic development to measure the level of creativity which a nation has. This index model was compiled by Florida, Mellander, and King, a group of researchers working at the Martin Prosperity Institute, a research institution based in the University of Toronto's Rotman School of Management, Canada. The model takes three dimensions of creativity, namely $3 T$ - technology, talent, and tolerance - to assess and rank 139 countries in the world (Florida, et al., 2015). The technology dimension is further measured by two elements: investment in research and development, and patents per capita. The talent dimension is measured from two more specific elements: part of the adult age group that has taken higher education, and part of the workforce included in the creative group. The last one, tolerance dimension is measured by various elements that reflect respects for immigrants and minority groups and LGBT groups (Lesbian, Gay, Bisexual, and Transgender).

The last element, respect to LGBT is in fact a controversial issue in many parts of the world. Many countries in the world are not able to respect LGBT based on their religious, social, political and cultural backgrounds, thus in the author's view, the relevance of LGBT element with creativity raises a big question. Therefore, this study will not incorporate respect for LGBT as one of the elements affecting creativity.

\section{Findings}

\section{Prospects and Challenges of Creative Economy in Indonesia}

The creative economy industry is growing steadily in Indonesia. Such a picture of Indonesian creative economy can be obtained from data taken from the previous research. A mapping study of the Indonesian creative industries conducted by the Ministry of Commerce of the Republic of Indonesia in 2007 results the contribution of Indonesian creative industry to Indonesian economy during period 2002 to 2006 as shown in column 3. The profile in the study is based on four main indicators. Data comparison of the similar indicators in the period of 2014 to 2015 is shown in column 5 (see Table 2).

Table 2: The Indonesian Creative Industry Profile - Past and Present

\begin{tabular}{|l|l|l|l|l|}
\hline No. & Indicators & $\begin{array}{l}\text { In Average } \\
\mathbf{2 0 0 2 - 2 0 0 6} \\
\mathbf{( 3 )}\end{array}$ & $\begin{array}{l}\mathbf{2 0 0 6} \\
\mathbf{( 4 )}\end{array}$ & $\begin{array}{l}\text { In Average } \\
\mathbf{2 0 1 4 - 2 0 1 5} \\
\mathbf{( 5 )}\end{array}$ \\
\hline 1. PDB based & & & \\
\hline & Gross Added Value (Rp Trillions) & 104.64 & 104.79 & 111.10 \\
\hline & $\%$ GDP & $6.3 \%$ & $5.67 \%$ & $7.05 \%$ \\
\hline 2. Employment based & & & \\
\hline$\quad$ Number of workers (millions) & 5.4 & 4.9 & 11.8 \\
\hline$\quad$ Employee participation rate (\%) & 5.8 & 5.1 & 10.7 \\
\hline 3. Export value based & & & \\
\hline$\quad$ Export value (Rp Trillions) & 69.6 & 81.4 & n.a. \\
\hline$\quad$ \% export value to total export (\%) & 10.6 & 9.1 & n.a. \\
\hline 4. Number of companies based & & & \\
\hline$\quad$ Number of companies (mill.) & 2.6 & 2.2 & n.a. \\
\hline & \% number of companies to total companies & 6.2 & 5.2 & n.a. \\
\hline
\end{tabular}

Source : Compilation from Indonesian Creative Industry Mapping Study, Ministry of Trade (2006) in the Ministry of Trade (2007) and BPS (2017) 
In the period of 2014 to 2015 , the added value from Indonesian creative economy sector is estimated at Rp111.1 trillion, an increase of Rp 6 trillion over the period of 2002 to 2006 . The highest contributors to the value added come from the fashion, culinary and craft subsectors. From its contribution to GDP, the creative industries in the 2014-2015 period have contributed Rp642 trillion or 7.05 percent of Indonesia's total gross domestic product (GDP), an increase of $0.7 \%$ compared to the 2002-2006 period. The biggest contribution that year came from culinary as much as 32.4 percent, from fashion 27.9 percent, and craft 14.88 percent. Whereas based on the data from BEKRAF (2016), from the growth of its contribution to national GDP, several sub-sectors in the creative economy have experienced significant growth, i.e. information technology (8.81 percent), advertising ( 8.05 percent), and architecture ( 7.53 percent). In addition to its contribution to national economy, in the 2014-2015 period Indonesian creative industry has become the fourth largest contributing sector in national employment, i.e. 10.7 percent or 11.8 million people. This figure means that the number of workers absorbed in the employment sector increases by 6.4 million compared to the period 2002-2006. Furthermore, based on the data from BEKRAF (2016), the level of worker participation during 2014-2015 also increases by almost 5\% compared to the level of participation during 2002-2006. From the labor absorption, the fashion business becomes the biggest contributor with a percentage of 32.3 percent, followed by culinary 31.5 percent, and craft 25.8 percent. The export growth to total exports during 2002-2006 is $10.6 \%$, while export growth data for the 2014-2015 period for comparison is not available. However, on a subsectoral basis, based on the data from Departemen Perindustrian (2016), during 2014-2015 it is found that the craft subsector records the highest growth of export contribution $(11.81 \%)$, followed by fashion (7.12 $\%)$, advertising (6.02\%) and architecture (5,59\%).

Another study associated with Indonesian creative industry is carried out by Fahmi (2014). The study finds that Bandung presents the development of creative industries based on science and innovation (eg. fashion style in distros, music genres). The contribution of universities (especially ITB), the creative community (especially Bandung Creative City Forum/BCCF) as a creative community alliance, and the Bandung City Municipal Government as local government are very significant. The Bandung municipal government supports the community activities by providing subsidies for the use of BCCF rooms, setting up policy research and framework, and integrates municipal and community programs. It has not been followed by other cities in Indonesia, which can only highlight the traditional culture industry without the development of new science and innovation. In this case, there is a need for encouragement for other local governments from the central government.

The other study on Indonesian creative industry was conducted by Bank Indonesia (2015). This study concludes that out of the five sectors investigated, i.e. handicraft, design, fashion, publishing and printing, and music industries, the first three sectors are competitive industrial sectors in Indonesia. The highly competitive handicraft industry sector can be found in the province of West Sumatra, South Sumatra, D.I. Yogyakarta, Banten, East Kalimantan, Central Sulawesi, and Maluku. The design industry sector is found in the province Kep. Riau, while the fashion industry is located in the province of Kep. Riau, West Java, D.I. Yogyakarta, East Java, and East Kalimantan. The current conditions provide various opportunities for the Government to develop the creative economy, to encourage the momentum of economic growth contribution from this sector. The first opportunity lies in the existence of potential creative classes, as part of the workforce working in the fields of science, technology and engineering; arts, culture, entertainment and media; business and management; education, health, and law. The percentage of creative classes in a country varies, from only $1 \%$ to more than $50 \%$ of the workforce for developed countries (Florida, et al., 2015). Hamdan (2016) states that until the year 2030, the population of productive age will reach approximately $60 \%$ of Indonesia's population, while by BPS (2016) estimate $27 \%$ of Indonesia's population of 296 million will be in the young age range (ages 16-30 year) which is the source of potential creative class.

The opportunity for the Indonesian creative economic growth comes from both domestic and foreign potential demand. From Indonesia only, with economic growth projected at 5-6\% per year, by 2020 the number of middle class people which are potential customers of the creative economy will reach 85 million, this number will increase to 135 million by 2030 (Afif, 2014). The opportunities for Indonesia creative economic sector will be increasingly enlarged with the integration of ASEAN and ASEAN partners due to larger target market (see Table 3 below). The ASEAN market covers a total population of 630 million people with $67 \%$ of them belongs 
to the productive age group. Moreover, escalated with the ASEAN integration with six other ASEAN partner countries, the market will expand and cover up to 3.5 billion people with 2.4 billion of them included in the productive age. If just one quarter of them belongs to the middle class, there will be 600 million potential consumers who become the target market. With the existence of e-commerce, the export of creative economy sector is no longer limited by distance and geographical location. The products of this sector will be easier to penetrate the world market, due to the ease of various internet facilities provided for ordering products. Indonesia's natural and cultural wealth has also the potential to become a source of inexhaustible "raw material" for creative economy, as long as it is well-preserved and managed.

Table 3: Population, productive age, cellular telephone users, and internet users in the ASEAN and ASEAN partners region (2015)

\begin{tabular}{|c|c|c|c|c|c|c|}
\hline \multirow[t]{2}{*}{ No. } & \multirow[t]{2}{*}{ Country } & \multirow[t]{2}{*}{$\begin{array}{l}\text { Population } \\
\text { (millions) }\end{array}$} & \multicolumn{2}{|c|}{$\begin{array}{l}\text { Number of productive age } \\
\text { (15-64 yrs) }\end{array}$} & \multirow{2}{*}{$\begin{array}{l}\text { Cellular } \\
\text { telephone } \\
\text { users per } 100 \\
\text { people }\end{array}$} & \multirow[t]{2}{*}{$\begin{array}{l}\text { Internet users } \\
\text { per } 100 \text { people }\end{array}$} \\
\hline & & & $\%$ total & millions & & \\
\hline 1. & Singapore & 5.54 & 73 & 4.03 & 146 & 82 \\
\hline 2. & Lao PDR & 6.8 & 61 & 4.18 & 53 & 18 \\
\hline 3. & The Philippines & 100.70 & 63 & 63.92 & 118 & 41 \\
\hline 4. & Malaysia & 30.33 & 69 & 20.96 & 144 & 71 \\
\hline 5. & Vietnam & 91.7 & 70 & 64.35 & 131 & 53 \\
\hline 6. & Thailand & 67.96 & 72 & 48.81 & 125 & 39 \\
\hline 7 & Cambodia & 15.58 & 64 & 10.01 & 133 & 19 \\
\hline 8. & Indonesia & 257.56 & 67 & 172.91 & 132 & 22 \\
\hline 9. & Brunei & 0.42 & 72 & 0.31 & 108 & 71 \\
\hline 10. & Myanmar & 539 & 67 & 36.16 & 77 & 22 \\
\hline 11. & Australia & 23.78 & 66 & 15.76 & 133 & 85 \\
\hline 12. & China & $1,371.22$ & 73 & $1,003.97$ & 93 & 50 \\
\hline 13. & India & $1,311.05$ & 66 & 859.99 & 79 & 26 \\
\hline 14. & Japan & 126.96 & 61 & 77.19 & 125 & 93 \\
\hline 15. & South Korea & 50.62 & 73 & 36.89 & 118 & 90 \\
\hline 16. & New Zealand & 4.6 & 65 & 2.98 & 122 & 88 \\
\hline
\end{tabular}

Source: Compilation from World Bank (2016) data

In line with the development of digital lifestyles, most of the productive age groups of Indonesia and the world today use communication devices (gadgets). Based on World Bank data, in 2015 there are 132 mobile cellular customers per 100 people and 22 internet customers per 100 people in Indonesia. It means most Indonesians subscribe to cellular telephone services, which some of them even have more than one cellular number. Moreover, about one of six cellular phone customers also subscribes to the internet package. Access to the creative economy becomes much easier thanks to the digital economy, creative goods and services can be promoted and traded with only touch on the screen of the gadget.

\section{The Comparison of Creative Economy Competitiveness}

As stated by the author at the beginning, this study assumes the level of creativity of a nation in line with the competitiveness of its creative economy. Indonesia's competitiveness in terms of creative economy in the world and ASEAN region is shown in Table 4. To describe Indonesia competitiveness, the author adopts the output of a study by a group of researchers from the Martin Prosperity Institute. The overall ranking in the world places Indonesia at the lower level - 115 of 139 countries. It automatically places Indonesia in the lower ranking group - 8 from 10 countries - in the competition of creativity among ASEAN member states. However, the author argues the ranking can be a little biased since the tolerance element is measured based on including the appreciation toward LGBT (Lesbian, Gay, Bisexual, and Transgender) groups, which in Indonesia the group are seen as an abnormality that needs to be cured. 
Sigit Setiawan / International Journal of Research in Business and Social Science,

Vol 7 No 2, 2018 ISSN: 2147-4486

Table 4: Relevant Global Creativity Index/GCI Ranking (2015)

\begin{tabular}{|c|c|c|c|c|c|}
\hline \multirow{2}{*}{$\begin{array}{l}\mathrm{GCI} \\
\text { Ranking } \\
\text { in ASEAN }\end{array}$} & \multirow{2}{*}{ Country } & \multirow{2}{*}{$\begin{array}{l}\text { World } \\
\text { Ranking }\end{array}$} & \multicolumn{3}{|c|}{ World Ranking } \\
\hline & & & Technology & Talent & Tolerance \\
\hline- & Australia & 1 & 7 & 1 & 4 \\
\hline 1. & Singapore & 9 & 7 & 5 & 23 \\
\hline 2. & Lao PDR & 42 & na & 97 & 23 \\
\hline 3. & Philippines & 52 & 54 & 65 & 53 \\
\hline 4. & Malaysia & 63 & 24 & 69 & 101 \\
\hline 5. & Vietnam & 80 & 45 & 104 & 73 \\
\hline 6. & Thailand & 82 & 38 & 84 & 105 \\
\hline 7 & Cambodia & 113 & 87 & 118 & 78 \\
\hline 8. & Indonesia & 115 & 67 & 108 & 115 \\
\hline 9. & Brunei & na & na & na & na \\
\hline 10. & Myanmar & na & na & na & na \\
\hline
\end{tabular}

Source: Compilation Data from Florida, et al. (2015). The authors are in Martin Prosperity Institute.

The map of technological competitiveness in the competitive level of creativity can better explain more properly Indonesian position at this time. The top technology index in the world is South Korea, which condition is supported by the country's high investment in research and development which reaches $4.3 \%$ of GDP, the number of researchers reaching 6900 per one million inhabitants, and government respects for intellectual property rights $(164,073$ patents are registered in the name of South Korean citizens, the data is taken from World Bank (2016)). In the global level, Indonesia ranks the 67th out of 139 countries in the world - it sounds good enough for an emerging country because it is in the middle ranking of the world technology index. But at the ASEAN level, competition has been so intense that Indonesia remains in the bottom position in the technology index. Indonesia is still only better than Cambodia. Meanwhile, Brunei, Laos and Myanmar do not have data available (see Table 5). Indonesia lags far behind South Korea, because the Indonesian government's investment support in research and development only reaches $0.08 \%$ of GDP, with the number of new researchers reaching 89 researchers per one million inhabitants, and a small number of patents of its citizens (702 patents) (the data is from World Bank (2016)). At the ASEAN level, Indonesia is still lagging behind Singapore with investment support in its R \& D of $2.2 \%$ of GDP and supported by an adequate number of researchers of 6,658 researchers from one million residents, and 1,303 patents of its citizens (such data is taken from World Bank (2016)). Institutionally, Indonesian government is still considered weak in providing protection by existing legal and legislative instruments for patents as intellectual property rights. In fact, similar conditions are also found in other developing countries.

Table 5: Global Technology Index

\begin{tabular}{|c|c|c|c|c|}
\hline \multirow[b]{2}{*}{$\begin{array}{l}\text { Technology Index } \\
\text { Ranking in ASEAN }\end{array}$} & \multirow[b]{2}{*}{ Country } & \multirow[b]{2}{*}{$\begin{array}{l}\text { World Technology } \\
\text { Index Ranking }\end{array}$} & \multicolumn{2}{|c|}{ World Ranking } \\
\hline & & & $\begin{array}{l}\text { R\&D } \\
\text { Investment }\end{array}$ & $\begin{array}{l}\text { Patents per } \\
\text { Capita }\end{array}$ \\
\hline & South Korea & 1 & 3 & 1 \\
\hline 1. & Singapore & 7 & 13 & 3 \\
\hline 2. & Malaysia & 24 & 30 & 22 \\
\hline 3. & Thailand & 38 & na & 51 \\
\hline 4. & Vietnam & 45 & na & 64 \\
\hline 5. & Philippines & 54 & na & 72 \\
\hline 6. & Indonesia & 67 & na & 81 \\
\hline 7. & Cambodia & 87 & na & 96 \\
\hline 8. & Brunei & na & na & na \\
\hline 9. & Lao PDR & na & na & na \\
\hline 10. & Myanmar & na & na & na \\
\hline
\end{tabular}

Source: Compilation Data from Florida, et al. (2015). The authors are in Martin Prosperity Institute.

Given the talent side of the creativity index, Indonesia ranking also does not help much. Indonesia is ranked 108th out of 139 countries in the world; this rank is still in the lower position. Meanwhile, Australia as the 
Indonesia neighboring country has the best talent index in the world. The tightly competitive condition which Indonesia is facing also also occurs in ASEAN. In the talent element, Indonesian people are still inferior compared to fellow ASEAN countries, except Cambodia. Meanwhile Brunei and Myanmar do not have available data (see Table 6).

Table 6: Global Talent Index Rankings

\begin{tabular}{|l|l|l|l|l|}
\hline \multirow{2}{*}{$\begin{array}{l}\text { Talent Index Rankings } \\
\text { in ASEAN }\end{array}$} & \multirow{2}{*}{$\begin{array}{l}\text { World Talent Index } \\
\text { Rankings }\end{array}$} & & World Rank & Creative Class \\
\cline { 3 - 5 } & & $\begin{array}{l}\text { Educational } \\
\text { Attainment }\end{array}$ \\
\hline- & Australia & 1 & 6 & 6 \\
\hline 1. & Singapore & 5 & 3 & na \\
\hline 2. & Philippines & 65 & 56 & na \\
\hline 3. & Malaysia & 69 & 49 & 66 \\
\hline 4. & Thailand & 84 & 81 & 46 \\
\hline 5. & Lao PDR & 97 & na & 86 \\
\hline 6. & Vietnam & 104 & 82 & 79 \\
\hline 7. & Indonesia & 108 & 86 & 74 \\
\hline 8. & Cambodia & 118 & 90 & 89 \\
\hline 9. & Brunei & na & na & na \\
\hline 10. & Myanmar & na & na & na \\
\hline
\end{tabular}

Source: Compilation Data from Florida, et al. (2015). The authors are in Martin Prosperity Institute.

As mentioned earlier, the talent dimension can be seen from creative class and educational attainment variables. The data for the creative class is taken by Martin Prosperity Institute from the International Labor Organization database for the period 2010 - 2012 (except Singapore and New Zealand covering the period 2004-2007). The creative class data shows part of the workforce requiring creativity in the working group. The scope of the work is actually quite extensive, varying from computer science, mathematics, architecture, engineering, natural and social sciences, education, training, literature, art and design, entertainment, sports, media, management, business and finance, law, marketing, to health care. All these jobs require specific knowledge or skills in the specific scientific branch. The ILO data adopted by Florida, Mellander, and King (2015) in Table 7 shows more clearly why Indonesia ranking of talent is in the lower position. Only $7.95 \%$ of the total Indonesian workforce works in sectors called the ILO as 'creative' work. When compared to Malaysia and the Philippines, Indonesia has lagged far behind, even more to Singapore which has the best percentage of creative classes in ASEAN and the top three in the world, with almost half of its workforce occupy jobs in the creative work sector. By far Luxemburg holds the best percentage of creative class, where more than half of its workforce do creative work. The worst condition goes to Guinea with only 75 people out of 10,000 workers do creative work.

Table 7: The number of Creative Class (\% national workforce)

\begin{tabular}{|l|l|l|l|}
\hline $\begin{array}{l}\text { Creative Class } \\
\text { Rankings in ASEAN }\end{array}$ & Country & $\begin{array}{l}\text { World Creative Class } \\
\text { Rankings }\end{array}$ & $\%$ Creative Class \\
\hline- & Luxemburg & 1 & 53,68 \\
\hline 1. & Singapore & 3 & 47,30 \\
\hline 2. & Malaysia & 49 & 24,05 \\
\hline 3. & Philippines & 56 & 21,33 \\
\hline 4. & Thailand & 81 & 9,85 \\
\hline 5. & Vietnam & 82 & 9,83 \\
\hline 6. & Indonesia & 86 & 7,95 \\
\hline 7. & Cambodia & 90 & 3,98 \\
\hline 8. & Brunei & $\mathrm{Na}$ & na \\
\hline 9. & Myanmar & $\mathrm{Na}$ & na \\
\hline 10. & Lao PDR & $\mathrm{Na}$ & na \\
\hline- & Guinea & 93 & 0,75 \\
\hline
\end{tabular}

Source: Compilation Data from Florida, et al. (2015). The authors are in Martin Prosperity Institute. 
Another element of the talent index dimension is the level of education participation at the higher education level. Higher education here does not only cover universities, but also covers all types of post-high school education or equivalent. The value of educational attainment is the ratio of higher education participants divided by the number of higher education age groups, which are in the range of $0-5$ years after graduating from high school level or equivalent. The lower ranking of Indonesia talent dimension in the world is inseparable from the low level of educational attainment or the level of education participation at the higher education level (see Table 8). In ASEAN, based on 2014 data, Indonesia is no better than the ASEAN main countries such as Thailand and the Philippines. Although there is no data for Singapore, but the progress that Singapore gains now in the higher education, finance, logistics, technology sectors is believed to be affected by the high average level of education that its citizens acquire, which is likely the best in ASEAN. Indonesia competes with Vietnam and Brunei, is better than Lao, Cambodia, Myanmar, and the good news is, Indonesia is better than Malaysia.

Table 8: The number of Educational Attainment (\% of national workforce)

\begin{tabular}{|l|l|l|l|l|}
\hline $\begin{array}{l}\text { Edu. } \\
\text { Rankings in } \\
\text { ASEAN }\end{array}$ & Country & $\begin{array}{l}\text { World Edu. } \\
\text { Att. Rankings }\end{array}$ & $\begin{array}{l}\text { Educational } \\
\text { Attainment } \\
(\mathbf{2 0 1 0})\end{array}$ & $\begin{array}{l}\text { Educational } \\
\text { Attainment } \\
(\mathbf{2 0 1 4})\end{array}$ \\
\hline- & South Korea & 1 & 99,66 & 95,35 \\
\hline 1. & Thailand & 46 & 50,20 & 52,51 \\
\hline 2. & Malaysia & 66 & 37,14 & 29,70 \\
\hline 3. & Indonesia & 74 & 24,20 & 31,10 \\
\hline 4. & Vietnam & 79 & 22,69 & 30,48 \\
\hline 5. & Lao PDR & 86 & 16,36 & 17,29 \\
\hline 6. & Cambodia & 89 & 14,06 & 15,90 \\
\hline 7. & Singapore & $\mathrm{Na}$ & na & na \\
\hline 8. & Philippines & $\mathrm{Na}$ & 29,75 & 35,75 \\
\hline 9. & Brunei & $\mathrm{Na}$ & 15,65 & 31,72 \\
\hline 10. & Myanmar & $\mathrm{Na}$ & 14,18 & na \\
\hline
\end{tabular}

Source: Compilation Data from World Bank (2016). Note : Brunei data is taken from year 2013 data as proxy

Approximately one of the three Indonesian citizens in the age range of higher education scholars attends higher education. This number is close to the number held by Malaysia, Brunei, the Philippines and Vietnam. Thailand is far enough to leave other ASEAN countries, where one in two Thai people in the age of tertiary education continues to higher education.

There is a close linkage here between technology index data and educational attainment data of the talent index dimension. South Korea can be the highest ranked country in the world in the technology index because it is also supported by, among others, the high participation of its citizens in pursuing to higher education, which number is also ranked the highest in the world. More than $95 \%$ of South Koreans at the age of higher education continue their education to tertiary education in 2014 . This figure even reaches almost $100 \%$ in 2010.

\section{Conclusion}

In comparison of the 2002-2006 and the 2014-2015 period data, it can be concluded that the average contribution of the creative economic sector to the Indonesian economy continues to increase steadily. The increase takes place in its added value, sectoral contribution to GDP, provision of employment, and sectoral absorption of national labor.

The opportunity of Indonesia creative economy in the ASEAN market lies in the growth of the middle class as potential customers, which data shows the number of middle class continues to increase by far. If it is assumed that a quarter of productive age (15-65 years) enters the middle class, then by 2030 the number of potential customers from within the country will reach 135 millions people, from the ASEAN market 160 million, and from the ASEAN + 6 market there will be 600 millions people. Potential consumer access to creative economic products are nowadays easier due to the ease of user-friendly internet and electronic transactions facility. 
By adopting and analyzing the output from the Global Creativity Index model, it can be concluded that the competitiveness of Indonesia creative economy in ASEAN and the world is still weak. This weak competitiveness is due to lower technology index and lower talent index. The lower technology index is contributed by the minor support of investments in research and development, a small number of researchers and the weak protection of intellectual property rights. Lower talent index is contributed by the small contribution of Indonesian labors working in the creative work sector.

From the results of previous studies in some regions of Indonesia, it appears that the Indonesian nation has a large creative potential to develop. Since creativity is produced from a combination of creative capital and creative space, the government support in facilitating the existence of both factors becomes important. The central government and local governments should work together in one understanding and perception collaborated with academics and the creative community to consistently encourage and facilitate the contribution of creative economic growth to the national economy.

\section{Acknowledgement}

The gratitude and appreciation goes to Irfa Ampri, PhD., the Deputy Head of Fiscal Policy Agency Ministry of Finance, Indonesia and Fithra Faisal, PhD for the insightful comments and suggestions.

\section{References}

Afif, S. (2014). The Rising of Middle Class in Indonesia: Opportunity and Challenge. University of Southern California, USA.

Bank Indonesia (2015). Kajian Peningkatan Akses Pembiayaan Bagi Industri Kreatif di Indonesia: Sektor Kerajinan. Departemen Pengembangan UMKM, Bank Indonesia. Jakarta, Indonesia.

Christensen, C.M., Raynor, M.E., \& McDonald, R. (2015). What Is Disruptive Innovation? Harvard Business Review, December 2015.

Departemen Perdagangan (2007). Pengembangan Ekonomi Kreatif Indonesia 2025: Rencana Pengembangan Ekonomi Kreatif Indonesia 2009-2015. Jakarta, Indonesia.

Department of Trade and Industry (2005). Creativity, Design and Business Performance. DTI Economics Paper No. 15, November 2005. United Kingdom.

Fahmi, F. Z. (2014). Creative Economy Policy in Developing Countries: The Case of Indonesia. Presented in ERSA 54th Congress, Saint Petersburg, Rusia, 26-29 August 2014.

Florida, R., Mellander, C., \& King, K. (2015). The Global Creativity Index 2015. Martin Prosperity Institute.

Florida, R., \& Goodnight, J. (2005). Managing for Creativity, Harvard Business Review, July-August 83 (7).

Hamdan, H. (2016). Kebijakan dan Strategi Pengembangan Ekonomi Kreatif. Deputi Bidang Koordinasi Ekonomi Kreatif, Kewirausahaan, dan Daya Saing Koperasi dan Usaha Kecil dan Menengah, Kemenko Perekonomian. Presented in Universitas Muhammadiyah Malang. Malang, Indonesia.

Howkins, J. (2013). The Creative Economy: How People Make Money from Ideas. Penguin, UK.

Martin, P., Morris, R., Rogers, A., \& Kilgallon, S. (2010). What are creative spaces? In P. Martin (Ed.), Making Space for Creativity. Chapter 4, University of Brighton.

Matthews, J. H. (2008). Developing Creative Capital: What can we learn from the workplace? In Proceedings Creating Value: Between Commerce and Commons. School of Management, Queensland University of Technology, Brisbane.

Nichols, T. (2003). Why Schumpeter was Right: Innovation, Market Power, and Creative Destruction in 1920s America. The Journal of Economic History, Vol. 63, No. 4 (December 2003). The Economic History. doi:10.1017/S0022050703002523.

United Nations, UNDP, \& UNESCO (2013). Creative Economy Report 2013. 